水 銀 中 毒 ${ }_{\text {第 } 1 \text { 編 }}$

Dithizone 法飞よる水銀の生体内分布飞関する研究

岡山大学医学部公衆術生学教室（主任 : 大田原一样教授）

専攻生 小 林 喬 三

[昭和 34 年 5 月 25 日受稿〕

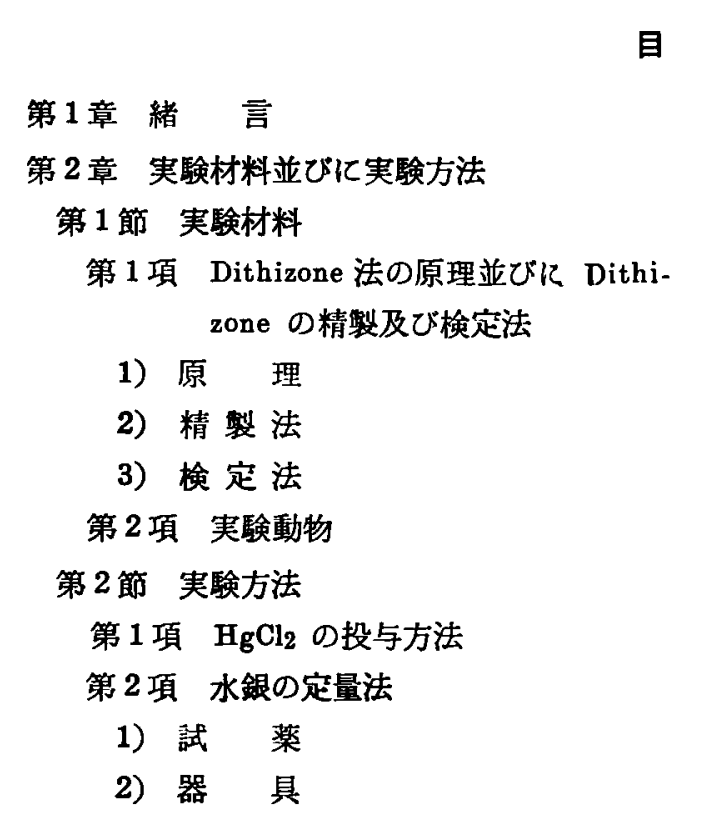

\section{第 1 章 緒言}

水銀中毒は我が国のみならず欧米諸国に於いても， 職業性疾患として鉛，珪肺，一酸化炭菜中毒等と共 に最む主要なものの一つである51)52)53)。

職業性水銀中䓯の臨休的研究に関するものとして は Letulle1), Leyden2), Braner ${ }^{3)}$, Borinsky4), Flury5), Stock6), Friberg7), Schulte ${ }^{8)}$, 尩9)，三

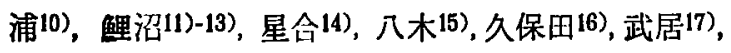
村上 (精)18）等の数多くの報告が発表されている.

第二次大戦後我が国に於いても，之の基硙的研究 の進少之学鿰衛生の向上により, 定型的な重症水銀 中毒患者は殆んどその影をひそめるに至つたのであ るが，軽症乃至潜在性の水銀中毒腎者の発生を見る ことは村上(俊)19)，橋場20)，及川21）等の研究によ り明らかなところである.

又水銀中毒の実験的研究としては Stock22)，Gil-
次

3) 可化法

a) 血液並びに腀器

b) 屎

4) 定星操作

a) 抽出法

b) 滴定法

第3 章 予備実験

第 1 節 添加試験

第 2 節 回収試験

第 4 章 実験成績

第 5 章 総括並びに考按

第6章 結 論

文献

y Gil23), William24), Fitzhugh25) 等の報告及び

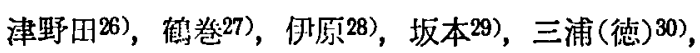
寺尾 ${ }^{31)}$ ，梅沢32)，菞地33）等の研究報告が癷表され ている.

次に水銀の定昆法に関しては，種々の物理的な方 法或は化学的な方法が用いられているが，有機物中 の水銀の测定は複雑な操作を要し，且鋭敏度の高い 試楽と雖む必ずしも特異的でなく，同時に存在する 他の「イオン」の障碍を受ける場合が多いことが注 意されている.

1926 年 Fischer ${ }^{34) 35)}$ により Dithizone 即ち Diphenylthiocarbazone が重金属の検出业びに定量 分析に応用されて以来, 之による水銀, 鉛, 銅等に ついての種々の定是法が相次いで報告されている。

Dithizone36) は $\mathrm{Au}, \mathrm{Pt}, \mathrm{Pd}, \mathrm{Ag}, \mathrm{Hg}, \mathrm{Sn}(\mathrm{II})$, $\mathrm{Cu}, \mathrm{Bi}, \mathrm{Zn}, \mathrm{Co}, \mathrm{Ni}, \mathrm{Pb}, \mathrm{Tl}, \mathrm{Cd}$ 等の全属「イオン」 と上記の順序で水に不溶性の溶剂中で反応するが, 
てれらの金属はそれぞれその反応条件を異にしてい る為，各金属を分離検出或は定量することが可能で ある3738)。即ち Dithizone と各種金属との反応は 水層中の $\mathrm{pH}$ が其の金属に最も適当した場合に起 るもので, この $\mathrm{pH}$ は各金属により異るため特定 金属の検出並びに定量は容易である。

Dithizone は多くの有機溶剂, 特に $\mathrm{CHCl}_{3}$ 並び 飞 $\mathrm{CCl}_{4}$ によく溶解して，各々金属特有の黄色，橙 黄色，赤色，柴色等の呈色反応を示す.

水銀は酸性溶液に於いてのみ Dithizone と反応 して $\mathrm{CHCl}_{3}$ 又は $\mathrm{CCl}_{4}$ に可溶の橙黄色の呈色反忍 を呈する。

本法の最有効範团は 1 200 rで其の测定誤差 は大体 1〜 5\%以内であるといわれている36).

Dithizone 法に於いても又金属「イオン」の妨害を 受けるため Sandell39) は Thiosulfate 塩及び Iodide塩試薬を用いることを推奖しでいる。

著者は Fischer ${ }^{34)}$ の方法に多少の改良を加え， 次に述へる方法で尿, 血液, 並びに各種葴器中の水 銀の销量定量を行い，急性昇永中毒モルモっトに於 ける生体内分布について検討し興味ある成績を得た のでその結果を報告する。

\section{第2 章 実験材料並びに実殹方法}

\section{第 1 節 実験材料}

第1 項 Dithizone 法の原理並びに Dithizone の精製及び検定法

1) 原 理

Dithizone は下記の如く Keto 型と Enol 型40) とがあるが分析学上には前者が重要である。<smiles>CCCCCNC(=S)N=Nc1ccccc1</smiles>

Keto 型<smiles>CCCCCNN=CS</smiles>

Enol 型
ての物質は水に不溶性で， $\mathrm{CHCl}_{3} ， \mathrm{CCl}_{4}$ 等の有 機溶剂に溶解して緑色溶液となる。

水銀を含有する酸性溶液を Dithizone- $\mathrm{CHCl}_{3}$ 溶 液と振擝するとDithizone 2 分子が $\mathrm{Hg}$ の 1 原子 之結合する41). 即ち $\mathrm{Hg} 1 \mathrm{mg}$ は Dithizone $2.6 \mathrm{mg}$ と反応して可溶性水銀化合物を生成して，Dithizone 固有の緑色は輝橙黄色に変化する。

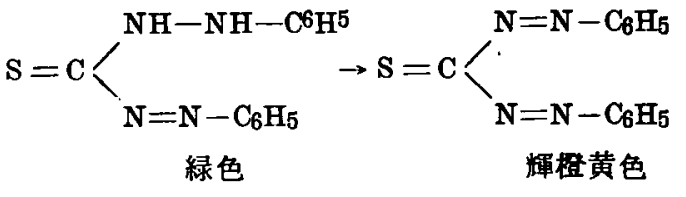

ての橙黄色は $\mathrm{Hg}$ が過剩に存在するかぎり持続 する. 此の際銅が微量に存在する場合は呈色を妨害 して緑色，赤色或は紫色を示す為に $\mathrm{Na}_{2} \mathrm{~S}_{2} \mathrm{O}_{3} \cdot 5 \mathrm{H}_{2} \mathrm{O}$ を加え，乙れを前以つて除去する必要がある。

尚酸性溶液中で Dithizone と呈色反応を示す金 属は第 1 表に示す如くである.

第 1 表 酸性溶液より抽出される金属

\begin{tabular}{c|c|c|c|c|c}
\hline \hline 反応金属 & $\mathrm{Pd}$ & $\mathrm{Au}$ & $\mathrm{Hg}$ & $\mathrm{Ag}$ & $\mathrm{Cu}$ \\
\hline $\mathrm{CHCl}_{3}$ & $\begin{array}{l}\text { violette-|hell- } \\
\text { flocken }\end{array}$ & $\begin{array}{l}\text { bräunlich } \\
\text { brange- } \\
\text { gelb }\end{array}$ & gelb & violett \\
\hline
\end{tabular}

Hg と略同様な着色を呈する金属は $\mathrm{Ag}$ のみで ある。乙の場合は $5 \%$ KI を加え强く振酮すれば Hg の場合は鮮緑色注邑するが，Agによるすの は不変である。

2）精製法42)(33)54)

Dithizone は屡々酸化物を含有して使用に堪えな い事があるので，下記の方法で精製する必要がある。

Dithizone 約 $1 \mathrm{~g}$ を約 $75 \mathrm{ml}$ の再溜 $\mathrm{CHCl}_{3} に$ 溶解する，圂濁を認める時は滤過して，乙れを分液 ロート中で $0.15 \% \mathrm{NH}_{4} \mathrm{OH} 100 \mathrm{ml}$ を加えて, よ く振毭して静置する。分層後 $\mathrm{NH}_{4} \mathrm{OH}$ 首は別の容 器に移し， $\mathrm{CHCl}_{3}$ 首は更に $\mathrm{NH}_{4} \mathrm{OH} 100 \mathrm{ml}$ を加え て4回抽出操作を行えば Dithizone は殆んど $\mathrm{NH}_{4} \mathrm{OH}$ 層に移行する. 乙の層を精製綿で媳過し, 別の分液ロートに入れて約 $10 \%$ v. HCl で酸性に すると Dithizone の沈溉を生ずる.

これ儿再溜 $\mathrm{CHCl}_{3} 20 \mathrm{ml}$ 宛を加えて数回振酒す ると Dithizone は $\mathrm{CHCl}_{3}$ 層に移行する. 次に再溜 水で $2 \sim 3$ 回水洗して 遮 光下で $50^{\circ} \mathrm{C}$ 以下で減圧 蒸発乾固する。

精製品は遮光の上 Desiccator 内に保存すれば相 当長期間任亘つて使用に耐えるか， $\mathrm{CHCl}_{3}$ 溶液に すれば数日で分解される為，必ず使用前に調整する 必要がある.

3）検定法43)

Dithizone の $10 \mathrm{mg} / \mathrm{dl}$ の $\mathrm{CHCl}_{3}$ 溶液の $10 \mathrm{ml}$ を分液ロートにとり，乙机に再溜水 $100 \mathrm{ml}$, 比重 約 $0.88 の \mathrm{NH}_{4} \mathrm{OH} 5 \mathrm{ml}$ 及び $10 \mathrm{~g} / \mathrm{dl} \mathrm{KCN}$ 溶液 $5 \mathrm{ml}$ を加えて振濫後静置する.

分層後 $\mathrm{CHCl}_{3}$ 居は無色となるべきで，黄色を呈 
した時は酸化物，又帯黄赤色乃至赤色の時は他の重 金属の含有が考えられる.

いつれれしてす呈色を示した時は精製を必要とす る.

尚 $\mathrm{CHCl}_{3}$ 層が Dithizone の固有色即ち緑色を呈 する時は $\mathrm{KCN}-\mathrm{NH}_{4} \mathrm{OH}$ 湿液 $100 \mathrm{ml}$ を加えて振湶 を繰り返すと完全にとれる。

第 2 項 実験動物

実験動物として体重 $500 \mathrm{~g}$ 前後のモルモットを 用いた。

実験前 1 週間のあいだは,「おから」，新鮮な野荣， 轧類等で飼育して，その健康状癿を確めた後实験に 使用した．被検尿は蓄尿を用いたか，その際资便の 混入しないように金網装置を施して採尿した。

\section{第 2 節 実験方法}

第 1 項 $\mathrm{HgCl}_{2}$ の投与方法

各動物とも0.196の $\mathrm{HgCl}_{2}$ を第 1 回 $2.0 \mathrm{ml}, 30$ 分 後第 2 回 $1.0 \mathrm{ml}$ をそれぞれ腹部に皮下注射法によ り投与した。

注射後 $\mathbf{5}$ 時間までの尿を採尿するとともに略々注 射 5 時間後全採血致死せしめて，肺葴，心臟，脾缄， 骨搭，肝臟，胃，小腸，盲腸，大腸等の一部或は全 部を摘出して湿重量として正確に計測し，Dithizone 法によつて水銀の化学的定量を行い，モルモットに 於ける水銀の生体内分布を追求した。

第 2 項 水銀の定量法

\section{1) 試 动}

試楽は凡て特級品を使用した。

\section{a) $\mathrm{KMnO}_{4}$}

b) $1: 1 \mathrm{H}_{2} \mathrm{SO}_{4}$, Conc. $\mathrm{H}_{2} \mathrm{SO}_{4}$

c) $5 \%, 50 \% \mathrm{NH}_{2} \mathrm{OH} \cdot \mathrm{HCl}$

d) $1.5 \% \mathrm{Na}_{2} \mathrm{~S}_{2} \mathrm{O}_{3} \cdot 5 \mathrm{H}_{2} \mathrm{O}$

e) Conc. $\mathrm{HNO}_{3}$ (比重1.40)

f) $\mathrm{KClO}_{3}(60 \%)$

g） $\mathrm{CHCl}_{3}$ (再溜したもの)

h) Dithizone-CHCl 3 溶液（D. T. L. 略記）

$$
\text { 抽出溶液 } 2.5 \mathrm{mg} / \mathrm{dl}
$$

滴定溶液 $0.125 \mathrm{mg} / \mathrm{dl}$

2) 器 具

a) 還流冷却器

b）分液口-卜（容量 $300 \mathrm{ml}$ )

c) Kjeldabl 消化管

d) Pippette

e) 試験管

f) Burette
硝子器具は凡て Pyrex 製を用いて，普通に洗湤 した後10\%の温 v. $\mathrm{HNO}_{3}$ でよく洗い，最後に再 溜水て数回洗旗して使用する。

3）灰化法44)45)

a) 血液业びに䤮器

Kjeldahl 消化管に検体 $10.0 \mathrm{~g}$ に対して $\mathrm{H}_{2} \mathrm{SO}_{4}$ $2.0 \mathrm{ml}, \mathrm{HNO}_{3} 15 \mathrm{ml}$ の割命に加え, 徐↔に GasBurner を用いて加熱して水分を蒸発させる．約 1 時間加熱した後，一度冷却して $\mathrm{KClO}_{3}$ 約 $2 \mathrm{ml}$ を 加え，更に加熱を続ける。しばらくすると液か浱縮 して $\mathrm{SO}_{3}$ の白煙が生じ，液が炏黄色澄明になれば 灰化は終了する，若し濃縮液が裮色乃至黑色となつ た時は更に $\mathrm{HNO}_{3}$ 並びに $\mathrm{KClO}_{3}$ を追加して, 再 び加熱を行い有機物を完全に分解する。

b) 尿

被験尿を容量 $300 \mathrm{ml}$ の還流冷却器付き Kjeldahl 消化管に入れ $\mathrm{H}_{2} \mathrm{SO}_{4} 2.0 \mathrm{ml}, \mathrm{KMnO}_{4} 0.5 \mathrm{~g}$ を加 え，徐々に加熱沸腾させる. $\mathrm{KMnO}_{4}$ が脱色しなく

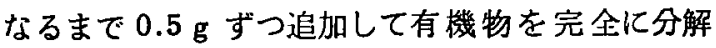
し室温で冷却する.

次に分解液に50\% $\mathrm{NH}_{2} \mathrm{OH} \cdot \mathrm{HCl}$ 溶液を加えて脱 色し，更に5\%6の $\mathrm{NH}_{2} \mathrm{OH} \cdot \mathrm{HCl}$ 溶液 $2 \mathrm{ml}$ を追加 して再び還流冷却器をつけて内容が沸滕するまで加 熱し，室温で冷却して検液とする。

4）定量操作

a) 抽出法

分解液を再溜水で稀釈し $\mathrm{H}_{2} \mathrm{SO}_{4}$ の浱度が約 $1 \mathrm{~N}$ になるように調製する。 とれを容量 $300 \mathrm{ml}$ の分液 ロートに入れ，D.T. L $(2.5 \mathrm{mg} / \mathrm{dl})$ を最初 $5 \mathrm{ml}$ 加元，密栓して約 1 分間強く振燳して静置する。 と の分層した D. T. L. 層は試料中の水銀量により炎 黄色加橙黄色を呈する。

更に D. T. L. $5 \mathrm{ml}$ を加えてよく振浧し，下部の D. T. L. 層が Dithizone の固有色即ち緑色となる まで抽出を反覆する。

次に別のフラスコに D. T. L. 抽出液を入れ，乙 th Aq. dest. $50.0 \mathrm{ml}, 11 \mathrm{H}_{2} \mathrm{SO}_{4} 2.0 \mathrm{ml}, 1.5$ 96 $\mathrm{Na}_{2} \mathrm{~S}_{2} \mathrm{O}_{3} \cdot 5 \mathrm{H}_{2} \mathrm{O} 4.0 \mathrm{ml}$, を加えて $50 \sim 60^{\circ} \mathrm{C}$ の水 榑中で処理すると，Dithizone- 水銀程は分雜して 水層に移行し, Dithizone-銅塩は $\mathrm{CHCl}_{3}$ 層にとど まる。

$\mathrm{CHCl}_{3}$ 層を唅て, $2 \mathrm{ml}$ の再溜 $\mathrm{CHCl}_{3}$ で数回水 首を洗い，水層中の渦剩の Dithizone 除去した 後, Kjeldahl 消化管に移し， $\mathrm{KMnO}_{4} 0.5 \mathrm{~g}$ を加え て還流冷却器をつけて約10分間徐々に沸滕させ, 室 
温で冷却する。

次に $5 \% \mathrm{NH}_{2} \mathrm{OH} \cdot \mathrm{HCl}$ 溶液を加えて過剩の $\mathrm{KMnO}_{4}$ を脱色した後, 更に $1 \mathrm{ml}$ を加え再び還流 冷却器をつけて汫腾させ, 室温で冷却して検液とす る.

b) 谪定法

水銀標準液： $\mathrm{HgCl}_{2} 0.1354 \mathrm{~g}$ を $\mathrm{N}-\mathrm{H}_{2} \mathrm{SO}_{4}$ に 溶解して $100.0 \mathrm{ml}$ とする。

使用時これを $\mathrm{N}-\mathrm{H}_{2} \mathrm{SO}_{4}$ で 100 倍に稀粎する．即 与 $1.0 \mathrm{ml}=10 \gamma \mathrm{Hg}$

上記標準波の一定量を分液ロートに正確にとり，

Aq. dest. を加えた後， $\mathrm{pH}$ を 1 前後に調䌘して滴 定用 D. T.L.を用いて谪定を行い，Dithizone の力 価を定める，次に前記抽出操作を行つた試料の一定 量を正確に分液ロートにとり，Aq. dest. を加え， $11 \mathrm{H}_{2} \mathrm{SO}_{4}$ で $\mathrm{pH}$ を 1 前後化調製する. 次いで谪 定用 D. T. L. をビュレットより分液ロートに少量 つつ谪下し，充分振盜すれば水銀による黄色乃至 橙黄色の呈色反応を示す. $\mathrm{CHCl}_{3}$ 層は捨て再び D. T. L. を滴下し，同様の操作を繰り返す．水銀 による黄色の呈色反応を示さなくなるまで抽出を反 覆する. 即ち Dithizone の最初の鮮緑色を示す点 を終末点とする. Dithizone の力価は定量毎に決定 する. 又 $\mathrm{pH}$ 亿関しては $3 \sim 4$ より 1 前後の方が 終末点がはるかに明暸であつた。

\section{第3章 予 備 実 験}

第 1 節 添加試験

水銀の標準液 $(10 \gamma / \mathrm{ml})$ 飞於ける直接滴定法を 前記の方法に彷つて行つた。

第 2 表 添加試 鈳

\begin{tabular}{|c|c|c|}
\hline $\begin{array}{c}\text { 水銀含有显 } \\
(\gamma)\end{array}$ & $\begin{array}{c}\text { D. T. L. の消費量 } \\
\text { (ml) }\end{array}$ & 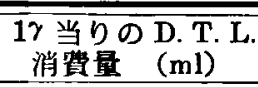 \\
\hline 1 & 3.0 & 3.0 \\
\hline 2 & 5.4 & 2.7 \\
\hline 5 & 10.5 & 2.1 \\
\hline 10 & 20.0 & 2.0 \\
\hline 10 & 20.8 & 2.08 \\
\hline 20 & 38.2 & 1.91 \\
\hline 20 & 38.6 & 1.93 \\
\hline 20 & 40.0 & 2.0 \\
\hline 30 & 56.0 & 1.87 \\
\hline 30 & 58.4 & 1.95 \\
\hline 80 & 146.4 & 1.83 \\
\hline 80 & 150.0 & 1.88 \\
\hline
\end{tabular}

添加試験の成積は第 2 表任示す如くである. 即ち 水銀量が増加するに従つて $1 \gamma$ 当りの测定値は減 少の傾向を示し, 且 $5 \gamma$ より $30 \gamma$ 程度の間に於い ては測定浞差は此較的少ない。

\section{第2節 回収試験}

含有量既知の水銀溶液を加えた正常モルモットの 尿, 血液並びに諸臟器に於いて第 2 章に述へた方 法で湿性灰化後，水銀の定显法を実施し，回収試験 を試みた。その結果は第 3 表に示す如く極めて良好 第3表 回収試験

\begin{tabular}{|c|c|c|c|c|c|}
\hline 試 & 料 & $\begin{array}{c}\text { 重 量 } \\
\text { (g) }\end{array}$ & $\begin{array}{c}\text { 永 鉭添加 } \\
(\gamma)\end{array}$ & $\begin{array}{l}\text { 水 銸検出 } \\
(\boldsymbol{y})\end{array}$ & $\begin{array}{c}\text { 回収率 } \\
(\%)\end{array}$ \\
\hline \multicolumn{2}{|c|}{ 尿 } & 10.0 & 1.0 & 0.85 & 85 \\
\hline \multicolumn{2}{|c|}{ 尿 } & 10.0 & 5.0 & 4.8 & 96 \\
\hline 血 & 液 & 10.0 & 8.0 & 7.8 & 98 \\
\hline 焣 & 哓 & 3.5 & 10.0 & 10.0 & 100 \\
\hline 督 & 嘰 & 4.0 & 10.0 & 9.6 & 96 \\
\hline 肝 & 嘰 & 6.0 & 15.0 & 14.4 & 96 \\
\hline 心 & 嘰 & 2.0 & 20.0 & 18.6 & 93 \\
\hline
\end{tabular}

な成績を得た。

\section{第4章 実 験 成 縝}

各動物共 $0.196 \mathrm{HgCl}_{2}$ を第 1 回 $2.0 \mathrm{ml} 、 30$ 分後 第 2 回 $1.0 \mathrm{ml}$ を皮下注射法により投与して，5 時 間経過後の実験成縤は第 $4,5 ， 6 ， 7$ 表に示す如くで ある。

第4 表 モルモットK於ける水銀分布の化 学的定星成精

\begin{tabular}{|c|c|c|c|c|c|c|}
\hline \multicolumn{2}{|c|}{ 動物 番号 } & \multicolumn{5}{|c|}{ No. $1460 \mathrm{~g}$} \\
\hline & (g) & \begin{tabular}{|c} 
榕体是 \\
$(\mathrm{g})$
\end{tabular} & \begin{tabular}{|l} 
恰出量 \\
$(\mathrm{mg})$
\end{tabular} & $\begin{array}{l}\text { 総水 } \\
\text { 銀 } \\
(\mathrm{mg})\end{array}$ & 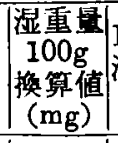 & \begin{tabular}{|} 
D.T.L \\
谪定値 \\
$(\mathrm{ml})$
\end{tabular} \\
\hline 尿 & 6.9 & 2.0 & 0.0113 & 0.0389 & 0.5650 & 22.5 \\
\hline 血 液 & 11.0 & 11.0 & 0.0082 & 0.0082 & 0.0745 & 16.6 \\
\hline 肺 㖪 & 2.6 & 2.6 & 0.0047 & 0.0047 & 0.1807 & 10.0 \\
\hline 心 糪 & 1.5 & 1.5 & 0.0035 & 0.0035 & 50.2333 & 8.0 \\
\hline 肝 搭 & 17.0 & 17.0 & 0.0100 & 0.0100 & 0.0588 & 20.0 \\
\hline 旅 & 0.7 & 0.7 & 0.0023 & 0.0023 & 0.3285 & 6.0 \\
\hline 叒 㬨 & 3.0 & 1.0 & 0.0300 & 0.0900 & 03.0000 & 56.0 \\
\hline 胃 & 5.2 & 4.0 & 0.0041 & 0.0053 & 30.1025 & 9.0 \\
\hline 小 晹 & 4.0 & 2.0 & 0.0024 & 0.0048 & 80.1200 & 6.2 \\
\hline 腸 & 11.0 & 4.0 & 0.0138 & $0.037 \mathrm{~s}$ & 90.3450 & 26.8 \\
\hline 大 晹 & 5.9 & 4.0 & 0.0049 & 0.007 & 20.1225 & 10.4 \\
\hline
\end{tabular}


・第 5 表 モルモットて於ける水銀分布の化 学的定量成䋹

\begin{tabular}{|c|c|c|c|c|c|c|}
\hline \multicolumn{2}{|c|}{ 動物番号 } & \multicolumn{5}{|c|}{ No. $2500 \mathrm{~g}$} \\
\hline & (g) & $\begin{array}{c}\text { 検体鼠 } \\
(\mathrm{g})\end{array}$ & $\mid \begin{array}{c}\text { 検出量 } \\
(\mathrm{mg})\end{array}$ & \begin{tabular}{|l} 
縃水 \\
銀量 \\
$(\mathrm{mg})$
\end{tabular} & $\left|\begin{array}{c}\text { 湿重量 } \\
100 \mathrm{~g} \\
\text { 換算值 } \\
(\mathrm{mg})\end{array}\right|$ & $\begin{array}{l}\text { D.T.L } \\
\text { 滴定僧 } \\
(\mathrm{ml})\end{array}$ \\
\hline 尿 & 5.6 & 2.0 & 0.0093 & 0.0260 & $0|0.4650|$ & \begin{tabular}{l|l|} 
&
\end{tabular} \\
\hline 血 液 & 12.0 & 12.0 & 0.0046 & 0.0046 & 60.0383 & 9.9 \\
\hline 肺 聯 & 3.3 & 3.3 & 0.0038 & 0.0038 & 80.1151 & 8.6 \\
\hline 心 羘 & 1.4 & 1.4 & 0.0024 & 0.0024 & $4 \mid 0.1714$ & 6.2 \\
\hline 肝 荿 & 14.0 & 14.0 & 0.0052 & 0.0052 & 20.0371 & 11.0 \\
\hline 脾 践 & 0.7 & 0.7 & 0.0024 & 0.0024 & 40.3428 & $\begin{array}{l}6.2 \\
\end{array}$ \\
\hline 毦 嚾 & 3.5 & 1.0 & 0.0282 & 0.0988 & 82.8250 & 53.0 \\
\hline 胃 & 4.6 & 4.0 & 0.0016 & 0.0018 & 80.0400 & 4.5 \\
\hline 小 腸 & 5.0 & 4.0 & 0.0020 & 0.0025 & 50.0500 & 3.5 \\
\hline 盲 腸 & 9.0 & 4.0 & 0.0130 & 0.0292 & 20.3250 & 25.4 \\
\hline 大 腸 & 5.7 & 4.0 & 0.0034 & $0.004 \varepsilon$ & 80.0850 & 7.8 \\
\hline
\end{tabular}

第 7 表 モルモットて於ける水銀分布の化 学的定量成績

\begin{tabular}{|c|c|c|c|c|c|c|}
\hline \multicolumn{2}{|c|}{ 動物 番号 } & \multicolumn{5}{|c|}{ No. $4 \quad 500 \mathrm{~g}$} \\
\hline & (g) & (g) & $\begin{array}{c}\text { 换出量 } \\
(\mathbf{m g})\end{array}$ & $\begin{array}{l}\text { 総水 } \\
\text { 銀量 } \\
(\mathrm{mg})\end{array}$ & 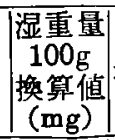 & $\begin{array}{l}\text { D.T.L. } \\
\text { 滴定值 } \\
\text { (ml) }\end{array}$ \\
\hline 尿 & 13.0 & 2.0 & 0.0138 & 0.0897 & 0.6900 & 28.0 \\
\hline 血 液 & 9.0 & 9.0 & 0.0055 & 0.0055 & 50.0610 & 12.0 \\
\hline 肺 㬴 & 2.6 & 2.0 & 0.0031 & $0.004 c$ & 0.1550 & 7.0 \\
\hline 哓 & 1.3 & 1.3 & 0.0050 & 0.005 & 0.3845 & 11.0 \\
\hline 肝 胅 & 14.0 & 14.0 & 0.0060 & 0.0060 & 0.0426 & 13.0 \\
\hline 脾 䑏 & 0.6 & 0.6 & 0.0027 & 0.0027 & 0.4498 & 6.0 \\
\hline 䢁 & 4.0 & 1.0 & 0.0387 & 0.1548 & 3.8700 & 73.0 \\
\hline 胃 & 5.0 & 4.0 & 0.0033 & 0.004 & 0.0825 & 7.5 \\
\hline 小腸 & 7.0 & 4.0 & 0.0045 & 0.0078 & 80.1125 & 10.0 \\
\hline 盲 腸 & 8.0 & 4.0 & 0.0085 & 0.017 & 0.2125 & 18.0 \\
\hline 大 晹 & 8.0 & 4.0 & 0.0055 & 00118 & 0.1375 & 12.0 \\
\hline
\end{tabular}

第6表モルモ,ト飞於ける水銀分布の化 学的定量成綪

\begin{tabular}{|c|c|c|c|c|c|}
\hline \multicolumn{2}{|c|}{ 動物 番号 } & \multicolumn{4}{|c|}{ No. $3 \quad 520 \mathrm{~g}$} \\
\hline 料 & $\begin{array}{c}\text { 総重星 } \\
\text { (g) }\end{array}$ & $\begin{array}{c}\text { 検体盈 } \\
\text { (g) }\end{array}$ & 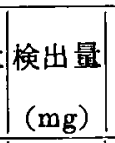 & 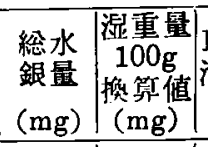 & $\begin{array}{l}\text { D.T.L.L. } \\
\text { 滴定值 } \\
\text { (ml) }\end{array}$ \\
\hline 尿 & 4.0 & 2.0 & 0.0133 & $0.0266 \mid 0.6650$ & 26.0 \\
\hline 血 液 & 7.7 & 7.7 & 0.0040 & 0.00400 .0519 & 8.8 \\
\hline 肺 㳀 & 3.2 & 3.2 & 0.0032 & 0.00320 .1000 & 7.5 \\
\hline 心 㺃 & 1.8 & 1.8 & 0.0034 & 0.00340 .1888 & 7.8 \\
\hline 肝 䑏 & 13.0 & 13.0 & 0.0055 & $0.0055 \mid 0.0423$ & 11.5 \\
\hline 脾 毖 & 0.5 & 0.5 & 0.0012 & 0.00120 .2400 & 3.5 \\
\hline 筒 腈 & 3.0 & 1.0 & 0.0381 & 0.11433 .8100 & 71.0 \\
\hline 胃 & 4.2 & 4.0 & 0.0026 & 0.00270 .0650 & 6.5 \\
\hline 小 腸 & 4.0 & 2.0 & 0.0024 & $0.0048 \mid 0.1200$ & 3.5 \\
\hline 盲 腸 & 8.5 & 4.0 & 0.0100 & 0.02120 .2500 & 20.0 \\
\hline 大 腸 & 5.5 & 4.0 & 0.0029 & $0.0039|0.0725|$ & 7.0 \\
\hline
\end{tabular}

湿重量 $\mathrm{mg} / 100 \mathrm{~g}$ とした場合の平均値は第 1 図に 示す如く，腎臟に最も著明に証明された，次に尿中 にあ比較的多量に証明されている，次いで脾缄，

盲腸，心蔵，肺葴，大腸，小腸，胃等の順位を示 した。

尚尿, 血液並びに各䑏器別に水銀の総含有量を見 ると，その平均値は第 2 図に示す如く堅䑏に於いて は最も多量であつた。次いで尿，盲腸，大腸，肝臟，

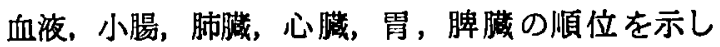
た。
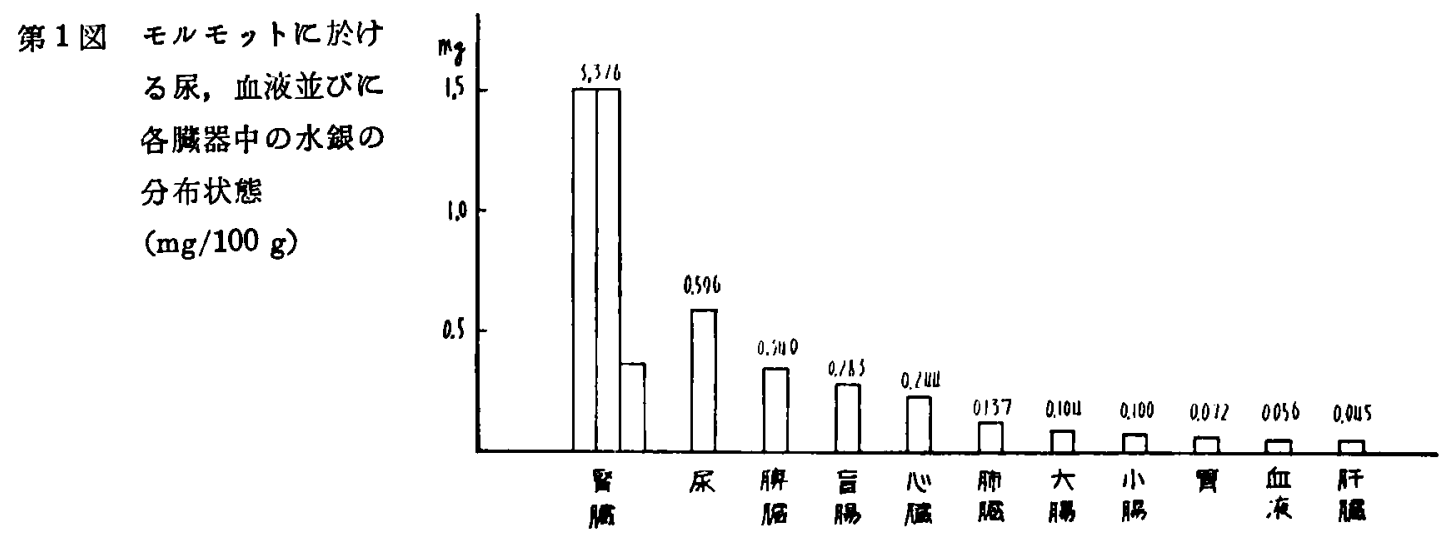
第2図モルモルモっトK 於ける尿，血液业 びに各䑏器中の水 銀の総含有量 (mg)

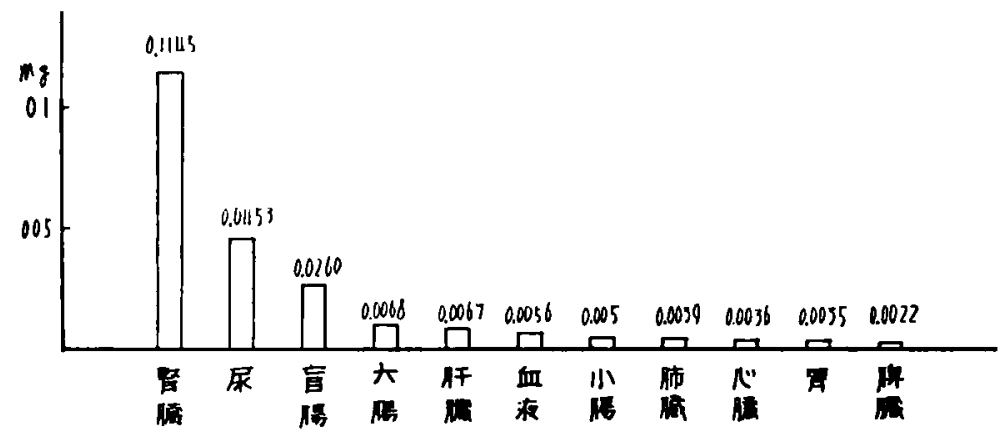

\section{第5章 総括並ひに考按}

尿並びに血液中の水銀量を測定することは，水銀 中毒を決定する望料として重要な指標となるばかり てなく，産業医学上潜在性水銀中毒患者の早期診断 にあ重要な意義のあることは論をまたない。

その测定法として彷来種々の理学的方法や化学的 方法が用いられていたか，著者は実験的に急性昇永 中毒に於けるモルモットの尿，血液並びに主要淢器 中に於ける水銀の分布状態を，Dithizone 法の一変 法を用いて微量定暴を行つた。

定聂方法は第 2 章に述べた如く試料を湿性灰化後, 所定の操作を行い水銀の含有量を則定した.

Dithizone 法による水銀の测定にあたつては，試 料の処理, 試楽り精製及び抽出操作等阔しては特 に微量化学的細心の注意を以つて行わ柿ならない. 水銀の回収試験は第 3 表に示す如く極めて好成績 を得ている.

モルモットの生体内に於ける水銀の分布状態に関 しては，卧搭に最も著明な沈着を示し，次いで屎中 に比較的多量に排泄され以下脾缄，盲腸，心脿，肺 茐，大腸，小腸，胃等の順位を示した，血液並びに

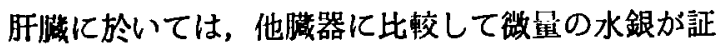
明された。

筒满内に多量沈着する原因については水銀は体内 梁入後，堅細胞特に細尿管細胞に多量蓄皘される為 と思われる。松田55) は腎䑏の Radiograph をとつ て見ると細尿管部に水銀の沈着が著明であると報告 している.

黒田46)，菊地33》は実験的に昇永中毒に於ける病 理組織学的変化は，留荿に最も著明で細尿管主管部 の壊死，润濁腫脹，上皮細胞の退行変化等を認めて おる．これらの点は腎䑏に於ける病理組織学的所見 と，水銀の沈着度とは比例するすのと思われる.

William 等24) による水銀蒸気吸入による家兔の 笑験に於いても，腎䑏は压倒的に多宜の记着を示し
ておる。

又梅沢32）はモルモっトに薬物感作原として水銀 軟䨋を慜擦せる場合，肺歲に最も著明で，次いで焣 臓，胃，皮盛の順序で訮䑏には微量を認めておる. 三浦30）は実験家兔に於いて血液中の水銀は，速 やかに消失して 1 時間後には 6 名に過ぎないと言い，

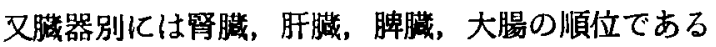
と報告している。

菊地33）は急性昇永中毒家鬼に於いて，血液亚び に肝䑏には铰量の水銀沈着を認めている，伊原28） は家兔に水銀を静脈内注射により投与した場合は堅

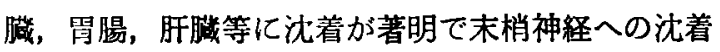
を認めていないが，蒸気吸入による場合は末梢神経 への沈着が最も著明であると報告しておる。

以上諸家の報告は著者の行つた，昇永中毒モルモ ットに於ける生体内分布と略々一致するむのと思わ れる.

其の他藤井47）の銅中毒家鬼に於ける実験では訮 㺃に著明で，次いで胆汁中に比較的多量を証明し， 留淽，尿の銅沈着は最も薇量であると埌告しておる。 又近藤48）の鉛中毒家鬼に於ける実験では腎䑏，胃， 肝䑏，肺の順に鉛星は隇少しておる，小川49）に依 れば亜鉛は膵淢，肝葴に多く沈着を認めたという。

銅，鉛，亜鉛等による中毒と，著者の行つた水銀 中毒に於ける分布状態とを比較すると著しく異つた 結果を示しておるが，重金属中毒の場合，金属の種 類，中毒の時期，動物の種類によつて分布状萔に可 成りの差異が認められるものと思われる。

水銀の蒸気吸入，注射及び塗擦による体内導入の 場合, 各䑏器に対する親和性の強弱が認められる事 は誠に興味ある事実である。

\section{第6 章 結論}

1） Dithizone 法の一変法により水銀の微量定量 を行つた，妨害「イオン」たる Cu“を適当な方法 で除去し，且試楽の精製並びに定星操作に充分注意 
すれば，鋭敏度が高く，有機物中の水銀の微量定显 には最も優れた方法である。

2）腎䐵は水銀に対して親和性が大であり著明の 沈着を認めた. 又尿はその排泄器管として腎䑋に次 いで比較的多量を認めた。

3）脾满，盲腸にも相当量の沈着を認め，次いで 心䑏，肺䑏，大腸，小腸，胃等の順位を示した。

4）肝䑏並びに血液に於いては水銀の沈着は微量 であつた.

5）尿, 血液並びに各議器別に於ける水銀の総含

文

1) Letulle, M. . Arch. d. Physiol. 1, 301, 437, 1887.

2) Leyden, E. : Dtsch. med. Wschr. 31, 733, 1893.

3) Braner. : Berl. Klin. Wschr. 267, 1897.

4) Borinsky, P. Klin. Wschr. 10, 149, 1931.

5) Flury, F. : Münch. med. Wschr. 25, 1021, 1926.

6) Stock, A. Münch. med. Wschr. 25, 1056, 1926.

7) Friberg, L. Hammarström, S. and Nyström, A. Arch. Ind. Hyg. \& Occup. M. 8, 149, 1953.

8) Schulte, H. . Arch. f. Hyg. 43, 83, 1914.

9）吳秀三：神経学雑誌，17，375, 大 7 .

10) 三浦譁之助：神経学雑誌，23，167，大12.

11）觟沼茄吾: 学働科学研究, 2,507, 大 14 .

12）䚤沼茫吾：颜業街生講座，5，141，昭13.

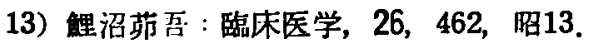

14）星合甚之助：日本之医界，18，8，昭 3 .

15）八木卓爾：当倒科学研究， 13,751 , 炤 11 .

16）久保田重孝：労㑬科学研究，18，732, 昭16.

17）武居䌘彦：结康保险医報，4，24, 昭13.

18）村上精次：应業医学，3，1，昭24.

19）村上俊雄 : 北海道医学雑誌，21，4, 昭18.

20）橋場亮二：北海道医学雑誌，29，324, 昭29.

21）及川富士雄：学值科学，31，11, 昭30.

22) Stock, A. und Cucuel, F. : Angew. Chem. 47, 641, 1934.

23) Gil g Gil . Zieglers Beiträge Z. Path. Anat. u. Z. Allgem. Path. 72, 621, 1924.

24) William, F. A. Edward, J. L. Frank, R. D. Donaed, M. H. and Morris, B. : Arch. Ind.

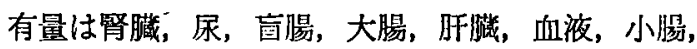

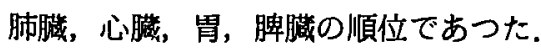

擱筆するに当り，終始御懇篤なる御指導並びに御 校閲の労を舓つた恩師大田原教授に対し深甚なる謝 意を表すると共に併せて種々の有益なる御助言言を 仰いだ緒方助教授飞深謝する。

（本論文の要旨は第11回日本公䍃衛生学会総会に 於いて発表した).

\section{献}

Hyg. \& Occup. M. 7, 19, 1953.

25) Fitzhugh, O. G. Nelson, A. A. Laug, E. P. and Kunze, F. M. Arch. Ind. Hyg. \& Occup. M. 2, 433, 1950.

26）津野田誠吾：中外医事新報，1105，493，1106, 565. 1107，619. 1108，683. 大15.

27）鶴巻恒松，荻生規矩夫，丸井栄太郎，日本桨物 学倠誌, 6, 329, 昭 2 .

28）伊原重彦：岡山医学会雑誌，43，176, 昭 6 .

29）坂本久雄：千葉医学会雑誌，71，821，昭 8 .

30）三浦德孝：千莱医学会雑誌，13，2439，2714, 昭10.

31）寺尾章照：名古屋医学三維誌，57，339, 佋18.

32）梅沢義一：日本法医学雑誌，4，5，昭25.

33）菊地桂助：日本法医学雑誌，5，93，四26.

34) Fischer, H. Angew. Chem. 42, 1025, 1929.

35) Fischer, H. : Angew. Chem. 50, 919, 1937.

36) Wichmann, H. J. : Ind. Eng. Chem. Anal. Ed. 11, 66, 1939.

37) Fischer, H. : Angew. Chem. 46, 442, 1933.

38) Fischer, H. . Angew. Chem. 47, 90, 1934.

39) Sandell, E. B. : Ind. Eng. Chem. Anal. Ed. 9, 464, 1937.

40) Fischer, H. . Angew. Chem. 47, 685, 1934.

41) Jacobs, M. B. : The Analytical Chem. of Ind. poisions. Hazards. and Solvents. 1. 2nd. Ed. 229, 1949.

42) Jacobs, M. B. : Chemicalanalysis of foodsand food products 128, 1938.

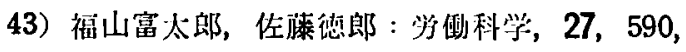
昭26.

44）福山富太郎, 佐藤德郎：学埗科学， 27,646 , 昭26. 
45）多田治：日本医事新報，1703，112，昭31。

46）黑田直 ·日本法医学雑誌，5，241，炤26.

47) 藤井克己：犯罪学雑誌，76，245, 昭17.

48）近藤実：岡山医学会雑誌，66，55，四29.

49）小川莎昭：薬局, 5,1240 , 昭 29 .

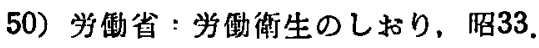

51) Patty, F. A. : Ind. Hyg. \& Toxy. 2, 643,
1949.

52）久保田重孝：最近の職業病，50，㗁28.

53）伊沢凡人：毒, 33, 昭18.

54）内藤多喜夫：有機試莧飞依る分析法，154，昭 19.

55）松四惊一：日本获理学雑誌，50，238，昭29.

\title{
Studies on Mercury Poisoning
}

\section{Part 1. A study on the in vivo distribution of mercury by Dithizone method}

\author{
By \\ Kyozo Kobayashi \\ Department of Public Health Okayama University Medical School \\ (Director; Prof. Dr. Kazuyoshi Ohtawara)
}

In the comparative study on the mercury distribtuion in the principal organs, blood, and urine of guinea pigs with acute sublimate poisoning, the author arrived at the following conclusions.

1. The microdetermination of mercury has been conducted by a modified method of the Dithizoie method. By properly eliminating $\mathrm{Cu}$ io. 1 which becomes an obstacle and by paying a sufficient precaution to the preparation of the reagent as well as to the determination procedures, a high sensitivity will be attained and for the microdetermination of mercury contained in organic substances such a method will prove to be an excellent one.

2. The kidneys are proven to show a great affinity to mercury, revealing a marked adsorption of mercury. In addition, the urine as an excretory carrier presents a relatively large amount of mercury next to the kidneys.

3. In the spleen and caecum likewise a considerable amount of mercury has been adsorbed, followed by the heart, lungs, large intestines, Small intestines, and stomach in the order mentioned.

4. The amount of mercury adsorbed in the liver and blood is insignficantly small.

5. The total amount of mercury contained in the urine, blood, as well as in the principal organs is greatest in the kidneys, followed by ths urine, caecum, large intestines, liver, blood, small intestines, lungs, heart, stomach, and spleen in the order mentioned. 